\title{
Comparison between Cloprostenol-induced and Spontaneous Oestrus Fertility in Dairy Cows
}

\author{
F Cairoli ${ }^{1}$, A Mollo ${ }^{2}$, MC Veronesi ${ }^{1}$, B Renaville ${ }^{3}$, M Faustini $^{4}$ and M Battocchio ${ }^{1}$ \\ ${ }^{1}$ Dipartimento di Scienze Cliniche Veterinarie - Sez. Clinica Ostetrica e Ginecologica Veterinaria, Milano; ${ }^{2}$ Dipartimento di Scienze Cliniche \\ Veterinarie, Padova; ${ }^{3}$ Dipartimento di Scienze degli Alimenti, Sez. Fisiologia Veterinaria e Nutrizione, Udine; ${ }^{4}$ Dipartimento di Scienze e Tecnologie \\ Veterinarie per la Sicurezza Alimentare, Milano, Italy
}

\begin{abstract}
Contents
A short calving to conception interval is of main importance to achieve high economic efficiency in dairy cow industry. In order to reduce this interval, several hormonal treatments have been put on the market, in which cloprostenol, a synthetic analogue of prostaglandin $\mathrm{F}_{2 \alpha}\left(\mathrm{PGF}_{2 \alpha}\right)$. The aim of this study was to compare fertility of cloprostenol-induced oestrus to that of spontaneous oestrus in dairy cows. In a group of 525 cows, 280 (treated group) were administered $0.5 \mathrm{mg}$ cloprostenol i.m. after transrectal corpus luteum (CL) detection, and inseminated at detected oestrus during the following week. The other 245 cows (control group) were inseminated during spontaneous oestrus. Whey progesterone concentrations were checked at treatment and at insemination in order to remove from the study cows whose P4 levels indicate a non-functional $\mathrm{CL}$, or a lack of luteolysis respectively. Moreover, cows that were not inseminated due to genital problems were also excluded from this study. Conception (59\% vs $54.5 \%)$ and calving rates $(93.7 \%$ vs $93 \%)$ were not significantly different between the two groups.
\end{abstract}

\section{Introduction}

The early resumption of normal cyclicity during the postpartum period is essential in order to obtain a high reproductive efficiency in dairy cow industry. To keep the calving interval under 365 days, cows have to be pregnant not later than 80-85 days postpartum. A delay in first ovulation or in first oestrus occurrence/detection is related with a lower conception rate $(\mathrm{CR})$ and a longer calving to conception interval. In fact, cows that had at least one oestrus before insemination showed better fertility compared with cows inseminated at the first postpartum oestrus (Rhodes et al. 2003). Moreover, cows not observed in oestrus up to 60 days postpartum have a significantly higher risk of being culled (Opsomer et al. 2000a), because in high-yielding and mediumyielding herds it can be profitable to reduce the number of animals with a long calving to conception interval (Esslemont et al. 2001). The percentage of cows with a prolonged postpartum anoestrus due to lack of ovulation within 44 days after calving (Lamming and Darwash 1998 ) is approximately $11-13 \%$ in the UK (Royal et al. 2000). In North America, the percentage of cows that are still in anoestrus 60 or more days after parturition varies between 23\% (Moreira et al. 2001) and 38\% (Lucy 2001). In Belgium, $22 \%$ of the cows do not ovulate within 50 days postpartum (Opsomer et al. 2000b).

The problem of prolonged postpartum anoestrus in dairy cows can be solved improving management or by using hormonal treatments. The aim of those treatments was to stimulate follicular development to induce oestrus and ovulation in cases of anovulatory anoestrus, and to induce luteolysis in cows not detected in oestrus, but with a detectable corpus luteum (CL) (Rhodes et al. 2003).

Prostaglandin $\mathrm{F}_{2 \alpha}\left(\mathrm{PGF}_{2 \alpha}\right)$ is a luteolytic substance commonly used in cattle as it can induce CL regression and fertile oestrus within 3-5 days after treatment (Inskeep 1973). For years PGF $_{2 \alpha}$ has been used in many protocols for induction or synchronization of oestrus, both as a single drug or in association with other hormones (Xu et al. 1997; Lopez-Gatius 2000; Diskin et al. 2002; Richardson et al. 2002; Taponen et al. 2002; Thatcher et al. 2002; Yaniz et al. 2004). On the contrary, Pursley et al. (1997) showed that $\mathrm{PGF}_{2 \alpha}$ administration does not result in an accurate oestrus/ovulation synchronization. These differences in treatment efficiency might be due to the fact that the $\mathrm{PGF}_{2 \alpha}$ was not administered at the same time during the cycle, resulting in a different follicular development (Kastelic et al. 1990).

The hypothesis explaining the low efficacy of $\mathrm{PGF}_{2 \alpha}$ in the first days of diestrus due to the lack of specific receptors during this phase was confuted years ago (Wiltbank et al. 1995). The mechanism of luteolysis seems to have a much more complex regulation, passing through gene expression modulating steroidogenesis, apoptosis, immune reaction and even the production of $\mathrm{PGF}_{2 \alpha}$ from the CL itself, together with structural and enzymatic modification of the luteal cells (Tsai and Wiltbank 1998). The neuroendocrine, paracrine and autocrine mechanisms involved in luteolysis regulation and $\mathrm{PGF}_{2 \alpha}$ action are still not completely understood (Skarzynski et al. 2000).

In relation to $\mathrm{PGF}_{2 \alpha}$-induced oestrus fertility, a retrospective study by McIntosh et al. (1984) highlighted the differences between the results reported by several authors, as well as the difficulty in comparing results due to the extreme variability of the experimental designs. Studies concerning the relationship between $\mathrm{PGF}_{2 \alpha^{-}}$ induced oestrus and fertility have also been presented in more recent studies, with some of them reporting positive or absent effect (Pankowski et al. 1995) and others finding negative effects (Xu et al. 1997).

Treatments of lactating dairy cows aiming at oestrous cycle control often provide unsatisfactory results, particularly in animals with high genetic value. This fact is presumed to be related to the typical low fertility of those animals, linked to the increasing selective pressure for high milk yield (Lucy 2001), but also to the negative energy balance (Butler 2002) and to an abnormal ovarian activity during the first part of lactation. 
Notwithstanding their increasing diffusion, treatments for oestrus synchronization are being debated once more, and a change in the results of $\mathrm{PGF}_{2 \alpha}$ administration is supposed to be connected to the intense selective pressure of the last years (Macmillan et al. 2003).

Therefore, the aim of this study was to evaluate fertility differences between cloprostenol-induced and spontaneous oestrus in dairy cows at the first postpartum artificial insemination (AI).

\section{Materials and Methods Animals}

The research was carried out over a 3-year period on 525 cows from two Italian Friesian cow herds (herd A $=290$ cows and herd $\mathrm{B}=235$ cows), located in northern Italy and characterized by $8850 \mathrm{~kg} / \mathrm{cow}$ milk yield $(3.95 \%$ fat, $3.48 \%$ proteins $)$ and $8540 \mathrm{~kg} / \mathrm{cow}(3.9 \%$ fat, $3.5 \%$ proteins) respectively. The cows were fed with a balanced diet formulated in accordance with the Nutrient Requirements of Dairy Cattle (2001).

Cows were clinically healthy, with normal cyclicity and in good body condition (BCS $=2.7-3$ ), one to six parity, not yet inseminated 60 days after calving.

On a total of 525 subjects, 280 cows (160 from herd A and 120 from herd B), were included in the group of treatment, while the remaining 245 animals (130 belonging to herd A and 115 to herd B) were used as control group.

\section{Treated group}

The 280 treated cows were administered i.m. with $0.5 \mathrm{mg}$ of cloprostenol (Estrumate ${ }^{\circledR}$, Mallinckrodt, Verona, Italy), a synthetic analogue of $\mathrm{PGF}_{2 \alpha}$ when a mature CL (identified on the basis of size, liver-like consistency, and the most likely presence of a basal stricture and ovulatory papilla) was transrectally clinically detected. During the week after treatment, animals were checked twice a day for oestrus detection. The cows showing oestrus, with a pre-ovulatory follicle and normal condition of genital tract (uterine tone, cervical mucus) were submitted to AI $12 \mathrm{~h}$ after the beginning of oestrus with semen of proven fertility.

\section{Control group}

The 245 control cows were submitted to the same diagnostic procedures, aimed at confirming the presence of feasible conditions for AI, at oestrus detection.

Evening milk samples were collected on the day of cloprostenol administration to evaluate the activity of the CL, as well as on the day of oestrus to verify the occurrence of luteolysis in the treated subjects and the absence of luteal activity in all inseminated animals (both treated and control cows).

\section{Hormonal analysis}

Progesterone (P4) levels in whey were measured by radioimmunoassay (RIA) using the technique described by Prandi et al. (1992). Intra-assay and interassay coefficients of variation $(\mathrm{CV})$ were $8.9 \%$ and $7.6 \%$ for diestral values and $18.6 \%$ and $18.3 \%$ for estral values respectively. On the basis of luteal activity, the CL was considered to be functional when $\mathrm{P} 4$ concentrations were $>382 \mathrm{pmol} / \mathrm{L}$ and absent when $\mathrm{P} 4$ concentrations were $<318 \mathrm{pmol} / \mathrm{L}$ (Prandi et al. 1994).

\section{Fertility analysis}

Fertility was evaluated by pregnancy diagnosis through palpation per rectum 7 weeks after AI and further confirmed at calving.

Conception rate (pregnant cows/inseminated cows) and calving rate (calvings/pregnant cows) were evaluated for significance using chi-square test. Statistical significance was set at $\mathrm{p}<0.05$.

\section{Results}

\section{Treated group}

Of the 280 cows treated following the clinical finding of a mature CL, $230(82.1 \%)$ showed signs of oestrus within 7 days of the closprostenol administration: 134 of $160(83.8 \%)$ from herd A and 96 of $120(80 \%)$ from herd B. Most induced oestruses (95\%) were detected between 3 and 5 days post-treatment, with the highest frequency $(57 \%)$ on the fourth day.

Whey progesterone analysis detected 207 of 280 $(73.9 \%$; herd $\mathrm{A}=74.4 \%$, herd $\mathrm{B}=73.3 \%)$ cows with diestral P4 levels $(398-2862 \mathrm{pmol} / \mathrm{L})$ on the day of cloprostenol treatment, as an evidence of functional CL presence: 119 of $160(74.4 \%)$ from herd A and 88 of 120 $(73.3 \%)$ from herd B.

The results of diagnosis of cows with clinical-detected mature CL, on the basis of whey P4 concentration measured on the day of treatment, are reported in Table 1.

Luteolysis, as evidenced by progesterone concentrations $<318 \mathrm{pmol} / \mathrm{L}$ (range: $32-302$ ), was seen in 175 of $207(84.5 \%)$ cows, 97 of $119(81.5 \%)$ from herd A and 78 of $88(88.6 \%)$ from herd B.

Only 161 of $175(92 \%)$ cows with cloprostenolinduced oestrus were submitted to AI, as 14 (herd $\mathrm{A}=9$, herd $\mathrm{B}=5$ ) did not show genital tract conditions suitable for AI.

\section{Control group}

Of the 245 cows from control group with spontaneous oestrus, $220(89.8 \%)$ showed whey P4 levels (35$308 \mathrm{pmol} / \mathrm{L})$ consistent with oestrus $(\mathrm{P} 4:<318 \mathrm{pmol} / \mathrm{L})$ on the day of AI: 120 of $130(92.3 \%)$ and 100 of 115 $(87 \%)$ belonging to herd $A$ and $B$ respectively (Table 2).

Table 1. Diagnosis of 280 cloprostenol-treated cows with clinicaldetected mature corpus luteum (CL) on the basis of whey P4 levels

\begin{tabular}{lccc}
\hline & Herd A & Herd B & Total \\
\hline Mature CL (clinical finding) & 160 & 120 & 280 \\
Functional CL (P4: $>382 \mathrm{pmol} / \mathrm{L})$ & 119 & 88 & 207 \\
\hline
\end{tabular}


Table 2. Cows with spontaneous oestrus compared with their whey P4 levels

\begin{tabular}{lccc}
\hline & Herd A & Herd B & Total \\
\hline Oestrus (clinical detection) & 130 & 115 & 245 \\
Oestrus (P4: $<318 \mathrm{pmol} / \mathrm{L})$ & 120 & 100 & 220 \\
\hline
\end{tabular}

Only 209 of $220(95 \%)$ non-treated cows were submitted to $\mathrm{AI}$, as 11 animals (herd $\mathrm{A}=6$, herd $\mathrm{B}=5$ ) did not show genital tract conditions suitable for AI.

\section{Fertility analysis}

The fertility data of cows with cloprostenol-induced oestrus and spontaneous oestrus submitted to AI with whey $\mathrm{P} 4$ concentrations $<318 \mathrm{pmol} / \mathrm{L}$ are presented in Table 3.

The frequency analyses pertaining to the considered fertility index (pregnancy and calving rates) were evaluated with chi-square test, both from the data of the two herds considered separately and together, and no significant difference was found between cows with cloprostenol-induced and spontaneous oestrus.

\section{Discussion}

During the postpartum period it is very common to use the $\mathrm{PGF}_{2 \alpha}$ with the aim of shortening the diestrus phase or synchronizing oestruses in order to avoid decrease of reproductive efficiency and the subsequent reduction of herd profitability. For this reason, the comparison between cloprostenol-induced and spontaneous oestrus fertility was assessed.

In the attempt to reduce as much as possible the interference of factors not directly connected with the fertility of oestrus, precise clinical restrictions were enforced. First, despite the clinical finding of a mature CL, cows with whey P4 levels $(<382 \mathrm{pmol} / \mathrm{L})$ inconsistent with a functional CL $(26.1 \%)$, were removed from the analysis of fertility.

In this study the accuracy of per rectum palpation for the presence of a functional $\mathrm{CL}$ was $73.9 \%$, confirming the unreliability of rectal palpation alone to assess the CL functionality, in agreement with findings previously reported by other authors (Ott et al. 1986; Kelton et al. 1991; Archbald et al. 1993; Hanzen et al. 2000).

This justify the use of whey P4 RIA concentrations which increased the precision of the diagnosis. The luteolytic efficiency $(84.5 \%)$, obtained with a single cloprostenol administration, was evaluated not only on the basis of oestrus signs observation, but also by the actual oestrus induction following a drop of whey P4 levels to values lower than $318 \mathrm{pmol} / \mathrm{L}$. It is difficult to compare this finding with the oestrous response rates to $\mathrm{PGF}_{2 \alpha}$ selection treatments $(55 \%$ and $78.2 \%)$ reported by Archbald et al. (1994) and Xu et al. (1997), respectively, because of different experimental designs.

A $10.2 \%$ of the cows showing spontaneous oestrus have been excluded from the control group as well, because they did not present P4 values $<318 \mathrm{pmol} / \mathrm{L}$, indeed, the mean P4 of cows in oestrus is under $318 \mathrm{pm}$ but for some individuals the P4 during oestrus can be higher because of a luteolysis still not completed. In order to avoid errors, cows with P4 higher than $318 \mathrm{pmol} / \mathrm{L}$ were excluded from the experiment even if they were showing oestrus.

Furthermore, it should be noted that the $6.8 \%$ of the cows $(8.7 \%$ of the treated vs $5.3 \%$ of the control group, n.s.), which were really showing oestrus, were not submitted to AI because of non-optimal genital tract conditions.

Hence, the fertility of 161 cows in which oestrus was induced by a single administration of $0.5 \mathrm{mg}$ cloprostenol was compared with that of 209 whose oestrus was spontaneous. Neither pregnancy rate (59\% vs $54.5 \%)$ nor calving rate $(93.7 \%$ vs $93 \%)$ showed significant differences. As well, no differences were found between the two farms in which the study was carried out. These results confirm our previous findings (Veronesi et al. 1996; Battocchio et al. 2000) obtained under the same experimental conditions. In fact, Veronesi et al. (1996) reported no significantly different pregnancy rates $(43.6 \%$ vs $52.1 \%)$ between cows with cloprostenolinduced oestrus and spontaneous oestrus respectively. Similarly, Battocchio et al. (2000) found pregnancy rates of $42.7 \%$ vs $51.5 \%$ (n.s.) in cloprostenol-induced oestrus and spontaneous oestrus respectively.

The rate of pregnancy loss was not significantly different between cloprostenol-treated $(6.3 \%)$ and control group (7\%) cows. Even if these values are a bit higher than optimal threshold ( $<5 \%$; Upham 1991), they should be considered as ranging in the actual mean values (7-18\%; David et al. 1971; Cavalieri et al. 2003).

In conclusion, data from this study showed the absence of significant differences concerning pregnancy and calving rates after the first AI performed at least 60 days postpartum, between cows with cloprostenolinduced and spontaneous oestrus.

The reduction of fertility of $\mathrm{PGF}_{2 \alpha}$-induced oestrus compared with spontaneous oestrus, reported by several practitioners, could be related to the simple evaluation of pregnant/treated cows, without taking into account diagnostic errors. In fact, in the present study, the diagnostic errors implied the exclusion of $42.5 \%$ treated cows and only $14.7 \%$ control cows during the subsequent steps of animal selection: $\mathrm{PGF}_{2 \alpha}$
Table 3. Conception and calving rates in cows with cloprostenolinduced and spontaneous oestrus

\begin{tabular}{|c|c|c|c|c|c|c|}
\hline & \multicolumn{2}{|c|}{ Herd A } & \multicolumn{2}{|c|}{ Herd B } & \multicolumn{2}{|c|}{ Total } \\
\hline & Treated & Control & Treated & Control & Treated & Control \\
\hline Inseminated & 88 & 114 & 73 & 95 & 161 & 209 \\
\hline Pregnant & $52(59.1 \%)$ & $61(53.5 \%)$ & $43(58.9 \%)$ & $53(55.8 \%)$ & $95(59 \%)$ & $114(54.5 \%)$ \\
\hline Calving & $49(94.2 \%)$ & $57(93.4 \%)$ & $40(93 \%)$ & $49(92.5 \%)$ & $89(93.7 \%)$ & $106(93 \%)$ \\
\hline
\end{tabular}


CL sensitivity, luteolysis, hormonal levels and genital tract conditions.

\section{References}

Archbald LF, Risco C, Chavette P, Constant S, Tran T, Klapstein E, Elliot J, 1993: Estrus and pregnancy rate of dairy cows given one or two doses of prostaglandin $\mathrm{F}_{2 \alpha} 8$ or $24 \mathrm{~h}$ apart. Theriogenology 40, 873-884.

Archbald LF, Constant S, Tran T, Risco C, Klapstein E, Elliot J, 1994: Effect of sequential treatment with prostaglandin $\mathrm{F}_{\mathbf{2} \alpha}$ and/or oxytocin on estrus and pregnancy rate of lactation dairy cows. Theriogenology 42, 773-780.

Battocchio M, Mollo A, Veronesi MC, Normando S, Faustini M, Messina M, 2000: Conception Rate in Dairy Cattle following Cloprostenol-induced Estrus. 4th Annual Conference ESDAR, 22-23.

Butler WR, 2002: Nutritional interactions with reproductive performance in dairy cattle. Anim Reprod Sci 60-61, 161174.

Cavalieri J, Eagles VE, Ryan M, Macmillan KL, 2003: Role of sensitivity of detection of oestrus in the submission rate of cows treated to resynchronise oestrus. Aust Vet J 81, 416421.

David JSE, Bishop MW, Cembrowicz HJ, 1971: Reproductive expectancy and infertility in cattle. Vet Rec 89, 181-185.

Diskin MG, Austin EJ, Roche JF, 2002: Exogenous hormonal manipulation of ova activity in cattle. Domest Anim Endocrinol 23, 211-228.

Esslemont RJ, Kossaibati MA, Allcock J, 2001: Economics of fertility in dairy cows. In: Diskin MG (ed.), Fertility in the High-producing Dairy Cow. British Society of Animal Science, Edinburgh, Scotland, pp. 19-29.

Hanzen CH, Pieterse M, Scenczi O, Drost M, 2000: Relative accuracy of the identification of ovarian structures in the cow by ultrasonography and palpation per rectum. Vet $\mathbf{J}$ 159, 161-170.

Inskeep EK, 1973: Potential uses of prostaglandins in control of reproductive cycles of domestic animals. J Anim Sci 36, $1149-1157$.

Kastelic JP, Knopf L, Ginther OJ, 1990: Effect of day of prostaglandin $\mathrm{F}_{2 \alpha}$ treatment on selection and development of the ovulatory follicle in heifers. Anim Reprod Sci 23, 169-180.

Kelton DF, Leslie KE, Etherington WG, Bonnet BN, Walton JS, 1991: Accuracy of rectal palpation and a rapid milk progesterone enzyme immunoassay for determining the presence of a functional corpus luteum in subestrous dairy cows. Can Vet J 32, 286-291.

Lamming GE, Darwash AO, 1998: The use of milk progesterone profiles to characterize components of subfertility in milked dairy cows. Anim Reprod Sci 52, 175-190.

Lopez-Gatius F, 2000: Short synchronization system for estrus cycles in dairy heifers: a preliminary report. Theriogenology 54, 1185-1190.

Lucy MC, 2001: Reproductive loss in high producing dairy cattle: where will it end? J Dairy Sci 84, 1277-1293.

Macmillan KL, Segwagwe BV, Pino CS, 2003: Associations between the manipulation of patterns of follicular development and fertility in cattle. Anim Reprod Sci 78, 327-344.

McIntosh DAD, Lewis JA, Hammond D, 1984: Conception rates in dairy cattle treated with cloprostenol and inseminated at observed oestrus. Vet Rec 115, 129-130.

Moreira F, Orlandi C, Risco C, Mattos R, Lopes F, Thatcher WW, 2001: Effect of presynchronization and bovine somatotropin on rates to a timed artificial insemination protocol in lactating dairy. J Dairy Sci 84, 1646-1659.
Nutrient Requirements of Dairy Cattle (2001) National Research Council, 7th edn. National Academy Press, Washington, USA.

Opsomer G, Laevens H, Steegen N, de Kruif A, 2000a: A descriptive study of postpartum anoestrus in nine highyielding dairy herds in Flanders. Vlaam Diergeneeskd Tijdschr 69, 31-37.

Opsomer G, Grohn YT, Hertl J, Coryn M, Deluyker H, de Kruif A, 2000b: Risk factors for postpartum ovarian dysfunction in high producing dairy cows in Belgium: a field study. Theriogenology 53, 841-857.

Ott RS, Bretzlaff KN, Hixon JE, 1986: Comparison of palpable corpora lutea with serum progesterone concentrations in cows. J Am Vet Med Assoc 188, 1417-1419.

Pankowski JW, Galton DM, Erb HN, Guard CL, Grohn YT, 1995: Use of prostaglandin $F_{2 \alpha}$ as a postpartum reproductive management tool for lactating dairy cows. J Dairy Sci 78, 1477-1488.

Prandi A, Comin A, Gabai G, Pischiutti A, Bono G, 1992: A technique for the direct measurement of progesterone in whey and its use for fertility control in dairy cows. Arch Vet Ital 43, 149-157.

Prandi A, Motta M, Tondolo A, Rossi C, 1994: Evaluation of the reproductive efficiency of Simmental and Friesian cows farmed in Friuli (Northeast Italy) by analysis of progesterone levels. Theriogenology 42, 65-78.

Pursley JR, Wiltbank MC, Stevenson JS, Ottobre JS, Garverick HA, Anderson LL, 1997: Pregnancy rates per artificial insemination for cows and heifers inseminated at a synchronized ovulation or synchronized estrus. J Dairy Sci 80, 295-300.

Rhodes FM, McDougall S, Burke CR, Verkerk GO, Macmillan KL, 2003: Treatment of cows with an extended postpartum anestrous interval. J Dairy Sci 86, 1876-1894.

Richardson AM, Hensley BA, Marple TJ, Johnson SK, Stevenson JS, 2002: Characteristics of estrus before and after first insemination and fertility of heifers after synchronized estrus using GnrRH, $\mathrm{PGF}_{2 \alpha}$ and progesterone. J Anim Sci 80, 2792-2800.

Royal MD, Darwash AO, Flint APF, Webb R, Woolliams JA, Lamming GE, 2000: Declining fertility in dairy cattle: changes in traditional and endocrine parameters of fertility. Anim Sci 70, 487-501.

Skarzynski DJ, Miyamoto Y, Okuda K, 2000: Production of prostaglandin $F_{2 \alpha}$ by cultured bovine endometrial cells in response to tumor necrosis factor- $\alpha$ : cell type specificity and intracellular mechanisms. Biol Reprod 62, 11161120.

Taponen J, Kulcsar M, Katila T, Katai L, Huszenicza G, Rodrigues-Martinez H, 2002: Short oestrus cycles and oestrous signs after premature ovulations induced with cloprostenol and gonadotropin-releasing hormone in cyclic dairy cows. Theriogenology 58, 1291-1302.

Thatcher WW, Moreira F, Pancarci SM, Bartolone JA, Santos JE, 2002: Strategies to optimize reproductive efficiency by regulation of ovarian function. Domest Anim Endocrinol 23, 243-254.

Tsai SJ, Wiltbank MC, 1998: Prostaglandin $F_{2 \alpha}$ regulates distinct physiological changes in early and midcycle bovine corpora lutea. Biol Reprod 58, 346-352.

Upham G, 1991: Measuring dairy herd reproductive F2 alpha performance. Bov Prac 2, 49-56.

Veronesi MC, Battocchio M, Mollo A, Messina M, 1996: Preliminary evaluation of conception rate following prostaglandin induced oestrus within 100 days after calving in dairy cows. Atti Soc Ital Buiatria 28, 365-370. 
Wiltbank MC, Shiao TF, Bergfelt DR, Ginther OJ, 1995: Prostaglandin $F_{2 \alpha}$ receptors in the early bovine corpus luteum. Biol Reprod 52, 74-78.

Xu ZZ, Burton LJ, Macmillan KL, 1997: Reproductive performance of lactating dairy cows following estrus synchronization regimens with $\mathrm{PGF}_{2 \alpha}$ and progesterone. Theriogenology 47, 687-701.

Yaniz JL, Murugavel K, Lopez-Gatius F, 2004: Recent developments in oestrus synchronization of postpartum dairy cows. Reprod Domest Anim 39, 86-93.
Submitted: 07.10 .2005

Author's address (for correspondence): Dr Maria Cristina Veronesi, Dipartimento di Scienze Cliniche Veterinarie - Sez. Clinica Ostetrica e Ginecologica Veterinaria, Via Celoria 10, 20133 Milano, Italy. E-mail: maria.veronesi@unimi.it 